Forbidden Memory, Unwritten History: The Difficulty of Structuring an Opposition Movement in the PRC

Jean-Philippe Béja

\title{
CpenEdition
}

Journals

Édition électronique

URL : http://journals.openedition.org/chinaperspectives/2623

DOI : $10.4000 /$ chinaperspectives.2623

ISSN : 1996-4617

Éditeur

Centre d'étude français sur la Chine contemporaine

Édition imprimée

Date de publication : 15 décembre 2007

ISSN : 2070-3449

Référence électronique

Jean-Philippe Béja, « Forbidden Memory, Unwritten History: The Difficulty of Structuring an Opposition Movement in the PRC ", China Perspectives [En ligne], 2007/4 | 2007, mis en ligne le 30 décembre 2010, consulté le 28 octobre 2019. URL : http://journals.openedition.org/chinaperspectives/2623 ; DOI : 10.4000/chinaperspectives.2623 
U

\title{
Forbidden Memory,
}

Unwritten History

\author{
The Difficulty of Structuring an opposition Movement \\ in the PRC
}

JEAN-PHILIPPE BÉJA

This paper suggests how control over transmission of memory by the Party, applying China's own dynastic tradition of reinterpreting history, and borrowing the Soviet practice of erasing people and events from records, has hindered the structuring of an opposition movement. Each resistance movement since 1949 has had to start from scratch as its actors, isolated from the past, always saw themselves as innovators. The paper analyses the 1957 Anti-Rightist Movement and the 1989 pro-democracy demonstrations to illustrate the thesis.

E ach of China's dynasties has sought to legitimize its power through new interpretations of history. After consolidating its rule, one of a dynasty's first acts has consisted of writing the history of the preceding dynasty. Although this tradition was interrupted by the establishment of the Republic in 1911, it has remained very important for Chinese rulers to ground their power in history.

This tendency has been reinforced by the fact that since 1949, China has been ruled by a communist party. Ever since the 1917 October Revolution, communist regimes have been known for their great ability to manipulate history. Comparing photographs of leaders, counting the number of feet and heads, dividing one by the other and finding something odd has been a pastime of many a Sovietologist. The Chinese Communist Party (CCP) has inherited both China's own tradition and the practice put in place by the Communist Party of the Soviet Union. Moreover, in the absence of elections or other forms of legitimizing power, mobilization of the past has played an essential role.

Anniversaries of various revolutionary episodes punctuate the lives of Chinese citizens. The founding of the CCP on July 1, Army Day on August 1, the anniversary of the May $4^{\text {th }}$ movement, and the proclamation of the People's Republic on October 1 provide opportunities to celebrate the unity of the people behind its leadership and, since television has made its way into every citizen's home, to eulogize old revolutionaries through interviews. History's presence is manifest even in the social structure itself, as the date of participation in revolutionary activities (canjia geming) is a crite- rion for promotion in the bureaucracy - the earlier one joined the Party, the higher one's rank.

The dates are obviously selected according to political criteria, and since the founding of the People's Republic, the list of celebrations has undergone many changes. While some of those mentioned above pertain to the continuity of the Party's rule, many others are linked to a certain political line: whereas 16 July 1967, the day Mao Zedong swam in the Yangtze, was celebrated all over China until 1976, (1) nobody thinks any more of mentioning the date, which brings back bad memories. The importance of historical dates was most strikingly revealed during the Cultural Revolution, when most Red Guard groups were named after the date of an event crucial for their existence.

However, manipulation of history and celebration of anniversaries are not an exclusive characteristic of CCP rule. All political regimes feel the need to ground their legitimacy in history, democracies being no exception. Even in Western countries, history is often manipulated by ruling parties, ${ }^{(2)}$ and any official history is inevitably manipulated to some extent by the ruling party. In the case of the People's Republic of China, however, there is only official history, and freedom of discussion in this area has always been either absent

1. On 16 July 1966, Mao Zedong swam in the Yangtze River in Wuhan (see Li Zhisui, The Private Life of Chairman Mao, London, Chatto and Windus, 1994, p. 406). After that, on every July 16 , all those who could swim dived into rivers, lakes and the sea to emulate the Great Helmsman.

2. One has only to consider the controversies in recent years in France over "memorials" linked to the Holocaust or to the colonial era. 
Doctored photograph : (from left to right) Zhu De, Mao Zedong and (only on the bottom photo) Liu Shaoqi, who fell victim to the Cultural Revolution.

or strictly limited. The following Soviet era anecdote could well apply to the Middle Kingdom:

Question heard on Armenian Radio - "Is it possible to foretell the future?"

Answer - "Yes, that's no problem. We know exactly what the future will be like. Our problem is with the past. That keeps on changing." ${ }^{(3)}$

The writing of history has been a vital exercise in all socialist countries, as their political leaders are supposed to have been designated by the laws of human development to accomplish the historical task of leading the people towards the glorious goal of communism. Therefore, when a leader is disgraced, he has to be erased from history books and can be remembered only in a negative way. The case of Liu Shaogi is quite revealing. Whereas during the 1950s he had been presented as a major leader of the working class movement before Liberation, he was labelled a scab during the Cultural Revolution, and schoolchildren were taught to hate his name. The same happened to Marshal Lin Biao, whose name was erased from the campaigns of the War of Liberation after he "betrayed" the Great Helmsman in 1971. He is a figure of contempt to this day. This is not the place to enter into all the details of how leaders were first erased and then reinstated in official history. But the numbers of officials assigned to this task and the care with which history is periodically rewritten show that the monopoly over interpretation of the past is deemed an essential instrument of political control by communist parties the world over. During the Cultural Revolution, this mania reached ridiculous extremes: subscribers to the Renmin Ribao regularly received notices asking them to scrap a page from a past issue because the author of an article had fallen from grace or because a piece of news had eulogized a person since labelled a counter-revolutionary. The need to control the past was so strong that during the late 1960s and the early 1970s, readers in public libraries were denied access to newspaper issues dating back more than a year.

\section{Control of memory:} an important part of political education

Controlling the official record of events, however important, is not enough. Besides mobilizing history to its service, the $\mathrm{CCP}$ has attached a special importance to controlling memory, which since the days of Mao Zedong has been an im-

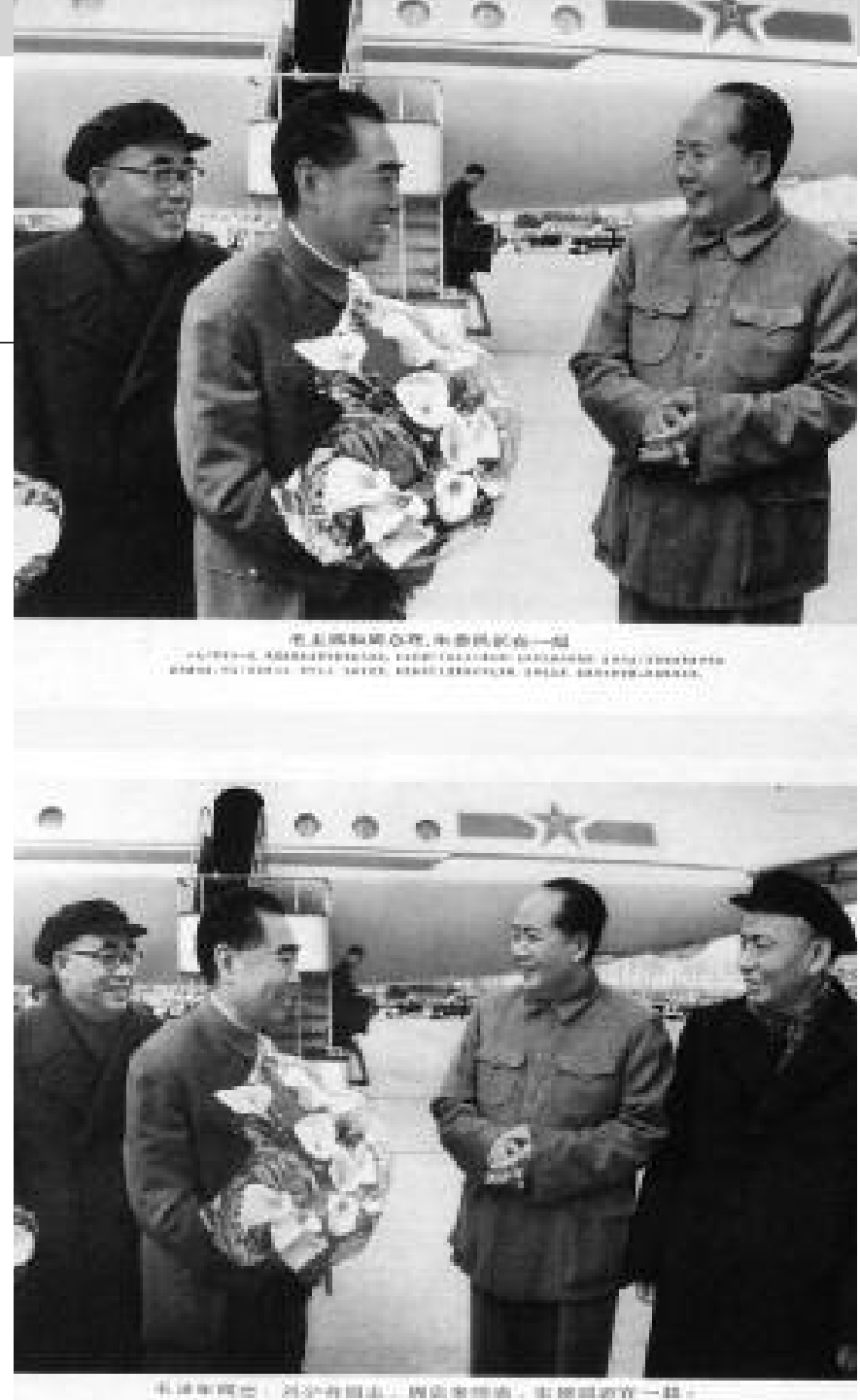

portant part of what was once called "class education" (jieji jiaoyu). Whenever sent to the countryside or to a factory for even a short visit, pupils from primary and secondary schools had to listen to old peasants or old farmers recall the suffering of the past - yiku sitian, or recalling the bitter (past) to appreciate the sweet (present). In the 1960s and the 1970s, these recitations represented an important part of the political upbringing of young people.

These were not descriptions of historical events, but stories of ordinary people that were supposed to make young people feel what life in the old society had been like and realize how lucky they were to live under the CCP's glorious leadership. The ritualised story-telling always started with a description of the utter poverty that reigned before Liberation (in factories, workers were made to toil for long hours for miserable wages, living in horrible slums, while in the countryside, landless peasants were compelled to do the hardest jobs for the landlords) and of hunger that was allpervasive. Then, the story reached a climax when the landlord (or capitalist) resorted to violence against the story teller (rapes were never clearly mentioned by women, but the audience could imagine it, as lust was presented as a typical feature of exploiters). The poor tried to resist but were impotent until one of them (usually the story teller) got in touch with the Red Army (the People's Liberation Army or 
PLA) which finally came to liberate the village (or the town) and put the people in power. In the 1970s in some places, the story did not end there, because very quickly many Communists were revealed to be rightists or revisionist agents of landlords; people had to wait until the Cultural Revolution was launched "by Chairman Mao himself" to be genuinely liberated.

These stories were manipulated by the leadership to serve ongoing struggles. Thus, in some places during the 1970s, yiku designated the suffering of ordinary people both under the Kuomintang regime and during the "17 years of the black revisionist line," and negative characters were as likely to be revisionist cadres as landlords (or capitalists). ${ }^{(4)}$ In the late 1970s, the situation was reversed - the bad guys became the "Gang of Four" and the rebels turned into careerists (yinmoujia).

These manipulated and ritualized memories have always constituted an important resource in the repertoire of CCP propaganda. Usually compiled under the supervision of Party secretaries, they obviously followed the political line of the moment, and roles were assigned accordingly. The tales of bitterness were considered an efficient complement to the official version of history taught in schools because they appealed to pupils' feelings while history manuals invoked reason. Since the Maoist era, "class feelings" (jieji ganqing) have been an important part of the character of the "new man," perhaps the more so as feelings towards the opposite sex were repressed. All those who were educated during the 1950s and 1960s were deeply impressed by these stories, which were part of any school outing. The appeal to emotion was manipulated to the extent that during the Cultural Revolution, cadres organized yiku fan ("remembering the bitter" meals) in which urban youths (but also, in some cases, young peasants) had to eat wild vegetables and all sorts of terrible foods that poor peasants were thought to have been reduced to consuming before Liberation. ${ }^{(5)}$

This emphasis on the use of manipulated personal memory to convey the political message of the moment shows that Communist leaders were aware of the importance of direct personal contact in the psychological formation of youths. It was actually quite efficient. Xu Youyu had this to say about youths during the Cultural Revolution: "Although two years of political movement had provoked doubt and suspicions towards political faith, certain ideas were deeply rooted in our minds, such as 'the old and the new society are two completely different worlds,' 'the complete liberation of poor peasants,' and that type of propaganda." ${ }^{(6)}$ These ideas obviously went hand in hand with hatred for landlords and the
Kuomintang, but also for peasants who resisted forced collectivization. In this official narrative, the peasants who had often fought for the CCP before Liberation, but had opposed its policies in the mid-1950s, were deemed to be the same as reactionaries. Thus, opposition to the CCP equalled opposition to the people. This aspect of the Party's monopoly over memory is one of the factors explaining the very long time it took for even the most radical Red Guards to question the regime's legitimacy.

Nevertheless, some examples show that even the most totalitarian regimes are unable to completely control the expression of memory. In a village in Henan, a rusticated youth was moved to tears by a "poor and middle" peasant's ${ }^{(7)} \mathrm{ac}-$ count of famine. In the discussion that ensued (an essential part of the unfolding of this typical séance of mobilization), the youths gave vent to their hatred of the Kuomintang landlords and their feudal allies, whose policies had led their class brothers to famine, to which the peasant replied: "But I am not talking of the days before Liberation. In those times we had plenty to eat. No, I'm talking about the terrible years 1960 and 61 [the Great Leap Forward]." ${ }^{(8)}$ This is not an isolated case. Xu Youyu said this of peasants in Sichuan:

Before the meetings, cadres explained many times to old peasants that while recalling bitterness, they shouldn't harp on the wrong bitterness; they should recall the pre-1949 bitterness, not the 1962 bitterness. Despite that, old people who were not clear about it talked about their sufferings in 1962, describing how terrible the famine had been, how a great many people had died of hunger. Because of the $\mathrm{Cul}$ tural Revolution propaganda, they would place the blame on Liu Shaoqi, but angry cadres would shout at them: "We ask you to remember Chiang Kaishek's bitterness, not Liu Shaoqi's!" (9)

These slips in the workings of the propaganda machinery led the youths of the 1960s to discover that propaganda was full

3. Quoted in Rubie Watson (ed), Memory, History, and Opposition, Santa Fe, School of American Research Press, 1994, p. 1.

4. This was the case in the many communes I visited as a student in Liaoning in 1976.

5. Xu Youyu, "Wode zaofan shengya: Shangshan xiaxiang nao geming (My experience of 'rebellion': Up to the mountains and down to the village to make revolution)," in Xu Youyu, Ziyou de yanshuo (Free speech), Changchun, Changchun Publishing House, 1999, p. 91.

6. Ibid.

7. As ordinary peasants used to be called (pingxia zhongnong).

8. Interview with a rusticated youth from Beijing, 1989.

9. Xu Youyu, Op cit, p. 92. 
of lies, and that all-out collectivization was loathed by all peasants, not only by the offspring of landlords, as official discourse had it. These uncontrolled memories therefore played an important role in the political formation of many a member of the "rusticated youth" generation and represented an essential step on the road to organizing opposition.

\section{Unwritten history}

Of course, the more importance the Party attaches to discourse about the past, the more it tries to control it. In a regime that holds no regular elections to confirm its leaders' legitimacy, history is an important asset. It was already the case in the Soviet Union: "Official history was the pivot of the regime's ideology, a regime which had no other sources to legitimate the Party monopoly on power. The specificity of official Soviet history, a modern avatar of 'divine right to rule' legitimacy, precisely comes from this peculiar situation." ${ }^{(10)}$

This can apply to the Chinese case too, but it is rarely as simple as the Party wants it to be. Often, official organizations such as the PLA or the CCP Central Committee have not played the exact role accorded to them in history manuals, which tend to present the conquest of power as a heroic struggle by Party members under the leadership of the Central Committee. Thus, historical events that do not corroborate this thesis cannot even be mentioned, and personal or family memories that differ from the Party line are mopped up with incredible vigour.

The writer Zhang Kangkang, in a novelette entitled Collective Memory, ${ }^{(1)}$ shows that even at the end of the twentieth century some events, although accomplished by Communists during the War of Liberation, have been expelled from history, and even from memory. Zhang's story is of a Party historian who must write a piece about the liberation of his city. He finds out that a woman who had studied abroad and become a Communist upon her return to China during the anti-Japanese war had played a major part in this event. Through her love for an engineer working with the KMT, she was able to save from destruction a strategic bridge that the PLA needed in order to continue its advance. When the historian tries to get information about that event, he finds no record of it in the archives and cannot get any confirmation from the old general who has entered history books as the city's liberator. In his interview with the historian, the general insists on the need to "take the big picture into account" and to dwell on the PLA's role. However, the historian refuses to give up and finally finds the woman. Having been labelled a Rightist in 1957, she has only just been rehabilitated. Living with her family in a tiny apartment, she has lost all illusions and refuses to tell him her story, thus expressing her conviction that her personal memory will never be allowed to challenge the official version of history. The story ends with the article being censored by the historian's superior. Although this story is presented as fiction, it refers to actual events. ${ }^{(12)}$ It illustrates that without the consent of the upper echelons, even a piece of history that has not been deemed negative by the Party cannot make its way into collective memory, and is even excluded from personal memory.

Naturally, episodes of resistance to Party rule have been eliminated more thoroughly from both official history and personal memory. "The colonization of public and private space is one of the hallmarks of state socialism." ${ }^{(1)}$

\section{To remember is to forget}

Psychologists have shown that forgetfulness is an indispensable element in the process of memory. No memory is possible if all details of a person's life are remembered: memory is a process of selection. The Party's memory therefore resorts to forgetfulness so as to build itself. But far from being a natural process as in the workings of memory analyzed by philosophers, in this case it is officially decreed and achieved by teams of specialists. Leaders indicate which part of past experience should be remembered according to the political line of the moment - for example, during the first three decades of the People's Republic, there was an insistence on identifying the class origin of people behind acts of sabotage - and on forgetting acts of resistance by peasants, Rightists or various kinds of so-called counter-revolutionaries.

During its first decades in power, when it was able to command the following of broad masses of people, the CCP was so keen on controlling the minds of citizens, especially youths, that it virtually banned people from passing on their personal ideas and memories, even to family members. "If the family head's political attitude coincided with the official one, he would forcefully encourage his children to become

10. Maria Ferretti, "La mémoire refoulée: La Russie devant le passé stalinien (Repressed Memory: Russia Confronts its Stalinist Past ), " Annales en Histoire et sciences sociales, November-December 1995, p. 1239.

11. Zhang Kangkang, "Jiti jiyi (Collective Memory)," Shouhuo, n6, 1999.

12. Interview with Zhang Kangkang, Beijing, 1999.

13. Rubie Watson, op. cit., 1994, p. 19. 
activists. Otherwise, the great majority encouraged their offspring to follow the official line, in the interests of their future. In many cases, people were afraid to express their disdain for the authorities, fearing they could be denounced by their children." And in fact, there were many instances of children "drawing a line of demarcation from their parents" (huaqing jiexian). ${ }^{(4)}$ Moreover, when people were targeted by a movement, their spouses divorced them so as not to be labelled counter-revolutionary as well. Those who refused to do so never talked about the spouse who had been labelled a reactionary, and who in many cases had been sent to the countryside for re-education, if not to jail. They especially refrained from presenting the spouse's ideas objectively to their children to let them judge for themselves. The pressure was so great that even in the hearth and home, family members resorted to officialese when talking to each other. People would use newspaper jargon to refer to the "crimes" of their spouses so that children would not "make mistakes" by using the "wrong" words while at school.

Further, memory as the transmission of the manner in which public events have been experienced - especially episodes of resistance - was carefully controlled by the authorities during the Mao era to the extent that, for instance, even the descendents of Rightists were unaware of the content of their parents' discourse. ${ }^{(15)}$ To them, their progenitors were counter-revolutionaries who had willy-nilly spoken against the people. As a result, when they had the opportunity to vent their frustrations against the regime, when Mao called upon them to "bombard the bourgeois headquarters," they could not call upon the experience of the previous generation. It would take them many years to trace the route that had cost their parents so dearly.

\section{The memories of Rightists and Red Guards}

During the Cultural Revolution, and the subsequent sending down of youths to the countryside, many young urbanites who blindly believed in Party propaganda and obeyed Mao's call were convinced that the 1957 Rightists had been counter-revolutionaries hostile to the people. The youths did not hesitate to persecute and beat them in the early years of the movement. Moreover, in their opposition to the excesses of what they termed the "new bourgeoisie," they never tapped the political legacy of the Hundred Flowers movement, out of ignorance and because memory of the movement had been obliterated. It was through the exchange of experiences - the "Great Linking-up" (da chuanlian) - or during their stay in the countryside that they began to see that the Rightists' ideas were not so outrageous.

It is worth quoting at length Wei Jingsheng's experience with a Rightist. In 1966, Wei was a radical Red Guard - of "good" class background, as his father was a military officer - and during the movement he had been involved with a group (Liandong, the United Action Committee) that had adopted a violent attitude against most "counter-revolutionaries." But despite his prejudices, reality made him change his mind and helped him take the path of opposition:

... An "old Rightist" we had met [during travels in Xinjiang] confessed to us that she would never have thought, when she joined the Party, that one day it would come to be controlled by such cruel and inhumane individuals as those currently in power. Such talk shocked us at first and we thought she deserved her "rightist" label. But ... she told us many real stories, including her own, which imparted her words with an authority that was difficult to deny and aroused great interest in me... The experience of "old Rightists" gave rise to another question: "Why are good people always defeated and why do bad ones always triumph?" Although she appeared very ill at ease with us because of her rightist background, I thought she was a good person and that people like her would never willingly have hurt the people's interest. To label her a "Rightist" had been wrong in the first place, and it was a scandal that such an honest and competent person had been deported to that isolated place... ${ }^{(16)}$

Wei is not the only dissident whose ignorance of the past delayed the process of realisation. Zhang Musheng was the son of a leading cadre who had gone voluntarily to the countryside in Inner Mongolia in 1965. His stay in that remote place had made him think that the peasants, hostile to collectivization, were "reactionary." But in 1966, talking to another rusticated youth who had adopted a policy of decollec-

14. Xu Youyu, "'Wenge' de qiyin (The root causes of the Cultural Revolution)," in Xu Youyu, Op.cit, p.141. This is not a specific feature of China alone: Pavel Korchaghin, the hero of How Steel was Tempered, made himself famous by denouncing his "reactionary" parents. In 2000, this book was well stocked in Beijing bookstores.

15. In his autobiography, Wei Jingsheng recalls the story of a Rightist he met in Xinjiang during the Cultural Revolution. When Wei went to tell her husband how she was faring, "the man refused to admit that he had any relation with his children's mother." See "Autobiographie de Wei Jingsheng (Wei Jingsheng's autobiography)," in V. Sidane and W. Zafanolli, Procès politiques à Pékin (Political trials in Beijing), Paris, Maspero, 1981, pp. 65-66.

16. Ibid., pp. 69-70. 
tivisation in an isolated brigade he led, Zhang started to wonder whether he had been mistaken: the problem might lie with the Party, not with the people, after all:

So he started to read prohibited books on the history of the communist international. He also read works by Chinese "Rightists," such as Ma Yanshu's speeches on demography, writings by Chu Anping denouncing the "Party empire" (dang tianxia), and big volumes of Rightists' opinions and criticism of the Party's rule, Ding Ling's "March $8^{\text {th }}$ is Good" and Wang Shiwei's "Wild Lilies"... He compared Liu's and Mao's speeches at the 7,000 cadres' meeting in 1962 and found out that China's problem could not be solved by merely applying class struggle... His personal experience in the countryside led him to re-evaluate Peng Dehuai's "anti-Party opinion." The documents addressed to the Party by the Rightist Lin Xiling in 1957 left a deep impression on him... In the words of one of Zhang Musheng's friends: "Today, we keep discussing politics, but we still have not seen through as thoroughly as the Rightists did in 1957." (17)

Ignorance of previous episodes of resistance and lack of transmission of such memory deprive the new generation of the rich heritage those experiences represent. The absence of a structured memory means that it has always been difficult to organise an opposition movement. As the only information about the Hundred Flowers movement came from political education classes under the CCP's absolute control, the Red Guards were unaware of the opinions that people who came to be labelled "Rightists" had expressed earlier, while denouncing their "reactionary ideology." Only when they personally experienced the absolutism of $\mathrm{CCP}$ rule did they extend the scope of their criticism to the regime as such. But at this stage, they lacked intellectual resources to develop their analyses. They could not use the Rightists' experiences and ideas. They had never heard of the journal Guangchang, founded by Peking University (Beida) students and prohibited in May 1957. They had to start from scratch, and they, too, founded "autonomous newspapers," but the language they used was far less sophisticated that than of the earlier Rightists.

Writing in the 1990s, Xu Youyu recalls how he ignored the warnings of his cousin who had been labelled a Rightist in 1957:

During the Cultural Revolution, he warned me as I went out each day to post dazibao on the city walls. But I did not heed his warnings. I thought: "Your anti-rightist movement was nothing. This time, the supreme leader himself has liberated the 'rightist students, 'he has guaranteed that there would not be any 'settling of accounts after the autumn harvest' ( $Q$ iuhou suanzhang)." (18) Later, I realized that I and my generation had been duped. I went to the countryside, and when I came back to the city three years later, I found my younger cousin busy writing dazibao, denouncing his school principal and participating in the education revolution. I felt very sad: once a generation has seen through deception, it immediately makes way for the next generation. When I tried to understand the cause of this phenomenon, I discovered the limits of individual discourse: the lessons of our generation's experience had not entered the collective narrative, had not become part of a collective memory, and the students who came after us had not heard of it. ${ }^{(19)}$

Xu's reflections show the contempt in which youths of the Red Guard generation held their elders. They were all the more surprised when later, either through personal contacts or through the reading of "forbidden materials," ${ }^{(20)}$ they found out that their predecessors had already covered a good part of the road to awareness. Thus, the wish of Tan Tianrong, a Rightist from Peking University, that "May $19^{\text {th }}$ [1957, the day the Democracy Wall started at Beida] and May $4^{\text {th }}[1919$, the beginning of the New Culture movement] will remain in the minds of our younger brothers and sisters, eternally encouraging the youths who will come later," ${ }^{(21)}$ has not been fulfilled. In the 1960s, even those most radically hostile to bureaucracy among the Red

17. Liu Xiaomeng, "Wenge zhong zhishiqingnian de miwang yu juexing (Ignorance and awareness of rusticated youths during the Cultural Revolution)," in Ji Cilin, Niu Han, Deng Jiuping (ed) Women dou jingliguo de rizi (The days we have been through), Beijing Shiyue wenyi chubanshe, 2000, pp. 512-3. All the titles quoted in this passage have been labelled reactionary by the authorities. The earliest, Wang Shiwei's Wild Lilies and Ding Ling's "March 8th is good," were written in 1942.

18. In 1966, work teams sent by Liu Shaoqi to Beijing universities had labelled most radical Red Guards as rightists or counter-revolutionaries. Later, Mao disbanded the work teams and rehabilitated the students.

19. Xu Youyu, "Jiyi yu shenghuo (Memory and Life)," an unpublished document sent by the author.

20. During the raids carried out in the early phase of the Cultural Revolution, many Red Guards stole books from the personal libraries of the "Stinking ninth" (Chou laojiu) i.e. intellectuals. Later, these books made their way to the countryside. Other youngsters took advantage of the prevailing chaos to go and read "forbidden books" in forgotten corners of libraries.

21. Tan Tianrong: "Jiujiu xinling (Save the souls)," in Niu Han, Deng Jiuping (eds), Yuan shang cao: Jiyi zhong de fanyou yundong (Grass on the Steppe, the Anti Rightist Campaign in Our Memory), Beijing, Jingji ribao chubanshe, 1998, p. 13. 
Guards ${ }^{(22)}$ were unable to draw inspiration from these writings, and thus were unable to escape the conceptual categories imposed by the regime. It is possible that if memory had not been controlled, the criticisms made by the Rightists might have helped them put up more effective resistance. It was only at the start of the twenty-first century that the discourses of 1957 were published.

In his preface to the first anthology of original writings of 1957, ${ }^{(23)}$ the noted literary critic Qian Liqun recalls that the discourse of the 1957 Rightists is still subject to some sort of taboo. He notes that during Peking University's centenary celebration in 1998, hardly anyone referred to that period, because "it (was) not easy to talk about it." Qian shares the firm view that obliteration of memory has been an important factor in slowing down China's political evolution:

Because for a very long time (even until now), we have forgotten these predecessors, these people who sacrificed themselves! Our historians (including myself) have not done our work! The books written about the 1957 period are so empty, so full of mistakes (miwu) that the "youths who came after" (who were really the hope of their predecessors) have no way of understanding it. This is a disgrace for those who have followed, for the scholars! ${ }^{(24)}$

The trilogy to which Qian wrote the preface is a rare one. In 2003, when Zhang Yihe, the daughter of "number one Rightist" Zhang Bojun, published her book entitled The Past is not like Smoke on her father and his comrades, it was banned on the mainland. ${ }^{(25)}$ In 2007, all attempts at organizing meetings to commemorate the Anti-Rightist Movement came to naught, as the Propaganda Department forbade them. Another book by Zhang Yihe on the ordeals faced by an opera singer labelled a Rightist in 1957 was also banned. ${ }^{(26)}$

\section{The end of Maoism and resurgence of memory}

The only way for forbidden memories to reappear, and for at least a part of obliterated history to return to the public sphere, is through a change of political line. But such a reemergence is constrained by strict limitations. Obviously, this is not unique to China. After the $20^{\text {th }}$ Congress of the Communist Party of the Soviet Union, books, meetings and family reunions tackled the subject of Stalinist repression. This was when Alexander Solzhenitsyn published his One
Day in the Life of Ivan Denisovich, when films described the "excesses" of the Stalinist period, when writers and ordinary victims returned to their families and began telling their stories. But they were not allowed to question the legitimacy of communist rule.

This kind of resurgence is not limited to communist systems. In Chile and Argentina, democratization has been accompanied by a flood of memories of victims of repression and reappraisal of recent history. In Morocco, since the coronation of Mohamed VI in 1999, the true history of political struggle and labour camps under Hassan II has made its way into the public domain and forms an important resource for pro-democracy parties. "Behind the avalanche of historical narratives and their interpretations, one can perceive that the state is progressively losing its monopoly on the writing of history." (27)

The aftermath of Mao's death was likewise a period in which memories obliterated for two decades or more reappeared with official sanction, and history was rewritten in order to lend legitimacy to Deng Xiaoping's line. However, here again, these texts had to respect the narrative drawn up by the authorities: whereas it was acceptable to denounce the "excesses" of the "Gang of Four," it was out of the question to attack Mao or the CCP. Besides, new narratives had to follow the yiku sitian structure, and rehabilitated persons had always to congratulate themselves on the excellent situation that prevailed following the $3^{\text {rd }}$ Plenary Session of the $11^{\text {th }}$ Party Central Committee held in December 1978. Many events that had not been re-evaluated could not be raised in public. For example, as the "decision on historical mistakes" adopted by the Central Committee in 1981 stated that the Anti-Rightist Campaign had been too broad, but was justified, it has never been possible to raise the question of its legitimacy in public, and all books that have been published about it have had to follow these guidelines.

But things go even further. In the early 1980s, the new leadership declared that the nation had to look towards the fu-

22. Cf. Yang Xiguang, "Zhongguo xiang he chu qu? (Whither China?)," in Révo Cul dans la Chine Pop (Cul Rev in Pop China), Paris, 10/18, 1974.

23. Anthologies of "reactionary views," especially those of rightists, were published as confidential editions (neibu) and served as fodder for denunciation campaigns.

24. Qian Liqun, Bu rong mosha de sixiang yichan (An ideological heritage difficult to negate), in Niu Han, Deng Jiuping (eds), Yuan shang cao: Jiyi zhong de fanyou yundong, Op Cit., p. 13

25. It was published in Hong Kong under the title Zuihou de Guizu (The last aristocrats), Hong Kong, Oxford University Press, 2004.

26. Lingren wangshi (Past stories of Beijing Opera stars), Hunan Wenyi Chubanshe, Changsha, 2007.

27. See Benjamin Stora, "Maroc, le traitement des histoires proches (Morocco, the treatment of recent history)," Esprit, 8-9, 2000, p. 91. 
ture in order to achieve modernization. To this day, although leaders who have initiated political reforms had themselves been victimized during the various movements launched by Mao, they have done everything in their power to block spontaneous acts of remembrance. The fact that in $1987 \mathrm{Liu}$ Binyan and Wang Ruowang were planning to organize a large-scale meeting in May to remember those who had dared criticize the Party 30 years earlier during the Hundred Flowers campaign was an important factor in the central authorities' decision to expel them from the CCP. ${ }^{(28)}$ Worse still, when $\mathrm{Xu}$ Youyu and a few friends decided in 1996 to publish a book series and a journal dedicated to the memory of the Cultural Revolution on the occasion of the $30^{\text {th }}$ anniversary of the movement's launch by Mao, they were prevented from doing so. When a Guangzhou periodical, Jiaodian, published a long article by $\mathrm{Xu}$ detailing the early events of 1966, ${ }^{(29)}$ it was closed down.

These acts make it hard to believe that the legitimacy of the post-1978 CCP leadership has been grounded in the denunciation of the decade-long Cultural Revolution. But they show that, whatever its judgement on a certain period, the Party is reluctant to forsake its monopoly on interpreting history. It is particularly suspicious of any eruption of personal memories that might contravene the official line. In fact, the controllers of ideology are convinced that if ordinary citizens are allowed to publish their views on a historical period, it would be the first step towards the publication of documents critical of the regime.

Ten years later, the authorities not only banned activities commemorating the Hundred Flowers movement and the Cultural Revolution, they also barred some historians from taking part in conferences abroad. ${ }^{(30)}$

It is clear that in the 1980s, the CCP relaxed its hold on the public sphere and was obliged to forsake its grip on the private lives of its subjects. The release of vast numbers of people who had been jailed for political reasons, and the rehabilitation of great numbers of "Rightists" and "counter-revolutionaries," gave rise to a flood of memories within families and among friends. In the early 1980s, while the leadership was exhorting the population to look to the future (xiang qian kan), inside crowded apartments, youths and elders were immersed in acts of remembering. Fathers told their true stories to their children, elder brothers to their younger siblings. Literary journals provided a locus for these forbidden memories to make their way into public consciousness through poems, short stories and novels (the so-called "scar literature" or shanghen wenxue). In official circles too, Party leaders started to write their memoirs, sometimes revisiting what a journalist has called "black holes of history." Some targets of Maoist political campaigns, such as Hu Feng, also wrote memoirs in which they presented a defence of their ideas. ${ }^{(31)}$

The denunciation of the Cultural Revolution that took place after Mao's death, especially during the 1980s, has given rise to a renewed wave of research into the history of the CCP's repression of dissent, which has continued and even grown through the 1990s. Many texts by Rightists and dissidents of the Cultural Revolution have been published on the mainland, thanks either to surviving relatives of the victims of various movements or to the dedication of some historians who have made the cause of rehabilitation of these anti-heroes the core of their lives. A distinction should be made between those whom the central authorities decided to rehabilitate and others whose rehabilitation resulted (in part) from lobbying by family members and historians.

Typical of the first category is the case of Hu Feng, whose rehabilitation in 1980 was widely publicised. Excerpts from his Wanyan shu were released in 1988, and it was eventually published in full on the $100^{\text {th }}$ anniversary of his birth. ${ }^{(32)}$ The case of the first famous intellectual dissident of the Communist system is more complicated. As he was personally denounced by Mao in 1942, Wang Shiwei was not among the first wave of rehabilitations in the late 1970s. Lobbying by his wife, Liu Bao, and his son, who wrote many letters to the Central Committee asking the authorities to clear Wang's name, was ignored for a long time. ${ }^{(3)}$ Only when historian Zhu Hongzhao became involved was Wang's case taken up. However, during his rehabilitation in 1991 it was merely denied that he had organized an antiParty clique of five persons and that he had been a Kuomintang agent. ${ }^{(34)} \mathrm{He}$ was not cleared of the accusation of being a Trotskyist, still a crime in China. However, thanks to this rehabilitation Wang's works, like Hu Feng's, have

28. Interview with Liu Binyan, Paris, May 1988.

29. Xu Youyu, "Wenhua da geming 30 nian ji" (Condolences for the 30 years of the Cultural Revolution), in Jiaodian (Focus), $n^{\circ}$ 1996, pp. 10-38.

30. The Party has, however, not been able to impose its control entirely: a university in Liaoning held a conference on the 40th anniversary of the Cultural Revolution in September 2006.

31. Hu Feng, "Jianshu shouhuo (Simple talk about my harvest)." Excerpts in Ji Cilin, Niu Han, Deng Jiuping (eds), Zhiiman congcongde huiyi (Memoirs in clusters of branches ) Beijing, Beijing shiyue wenyi chubanshe, pp. 1-78.

32. Hu Feng, Hu Feng Sanshiwanyanshu, Wuhan, Hubei Renmin chubanshe, 2003.

33. Liu Bao, "Qiyuan jin wei xue, xiang dang su buping," in Zhu Hongzhao, Wang Shiwei wenzun, Shanghai, Shanghai sanlian chubanshe, 1998, pp. 345-354.

34. "Guanyu Wang Shiwei tongzhi tuopai wenti de fucha jujeding (Decision regarding the reexamination of comrade Wang Shiwei's Trotskyist problem)," in Wang Shiwei wencun, Op cit. p. 355 
been published, and people who are interested in understanding the ideas of those who dared criticize the CCP in the past can consult them and draw lessons from their failure.

More than any other field, memory makes up a major stake in the continuing dispute pitting the $\mathrm{CCP}$ against the people.

\section{Black holes in contemporary history}

Despite the intensity of control, some unofficial anniversaries (i.e., those not recognized by the authorities) have become rallying points for forces of resistance. The anniversary of the April $5^{\text {th }}$ (1976) Tiananmen Incident is the most obvious instance: Whereas the leadership was trying to obliterate Zhou Enlai's political heritage (after his death in January that year), various groups opposed to Mao's policy decided to celebrate Zhou's memory on Qing Ming, the traditional Festival of the Dead. ${ }^{(35)}$ The demonstration was severely suppressed, but to many people the date became a landmark of resistance. People denouncing the "leftist" line in 1977 and 1978 chose the same date to put up posters critical of past Maoist policies and the leadership of Hua Guofeng. As it enjoyed a strong backing inside the Party apparatus, the movement eventually prevailed: on 15 November 1978, Deng Xiaoping rehabilitated the April $5^{\text {th }}$ demonstration in an effort to eliminate his neo-Maoist rivals. Later, the poems through which anonymous writers had denounced the "feudalism of the new Qin Shihuang" (a covert reference to Mao) were published officially.

However, April 5th has not found a place in the official calendar of celebrations beside October $1^{\text {tst }}$, May $4^{\text {th }}$, July $1^{\text {st }}$ and August $1^{\text {st }}$. The fact that the demonstration was a case of spontaneous action by the masses explains the caution with which the authorities treat it. For each episode that has made it into official memory, how many more remain absent from history books? Take the case of the Democracy Wall Movement in 1978-79, during which a good number of exRed Guards expressed their criticism of the regime that had sent them off to the countryside for a decade. For a few months, underground journals carrying theoretical documents that discussed the nature of the regime and the way to resolve its problems circulated in many cities. ${ }^{(36)}$ Many concerned youths, especially those who had just returned from the countryside, took part in discussions on ways to avoid a repeat of the tragedy. Most of them agreed on the need to set up autonomous organs of public opinion to su- pervise the CCP. The articles in these ephemeral publications were never published on the mainland, and even now not a single book refers to their contents. The expression Minzhu qiang (Democracy Wall) is itself totally absent from official discourse.

Times have changed since the Anti-Rightist Movement. Since the 1980s, the Party has lost the capacity to control private discourse, and people who took part in the movement can discuss their experiences with others in their homes. However, circulation of the ideas expressed during these two years has been effectively interrupted, and they are not part of the common cultural heritage of would-be opponents. ${ }^{(37)}$ In this sense, their fate was similar to that of the articles published in Guangchang in the late 1950s.

In fact, students who took part in discussions about political reform in the salons of the late 1980s - the youths who were to take the lead in the 1989 Democracy Movement knew nothing of the debates that had taken place a decade earlier between the radicals led by Wei Jingsheng, who founded Tansuo (Exploration), and moderates around $\mathrm{Xu}$ Wenli's Siwu luntan (April $5^{\text {th }}$ Forum). ${ }^{(38)}$ They knew more about political debates in Western countries than about the episodes of resistance that had taken place within China since 1949.

The absence of a structured memory prevented these activists from drawing the lessons of the past in the field of organization: "Democracy Wall" activists had tried to set up local and national associations, had founded unofficial journals and had accumulated rich experience in dealing with the authorities. They were eventually repressed but their experience was precious. However, they could not transmit it to the younger generation, which had to start from scratch and to create its own concepts in order to understand the system's workings. Of course, some "Democracy Wall" participants were also active in the 1989 Democracy Movement, ${ }^{(39)}$ but dialogue was difficult with the students, and they could not fully use their experience in organizational work.

35. See Claude Cadart, Cheng Ying-hsiang, Les deux morts de Mao Tse-toung (The two deaths of Mao Zedong), Paris, Seuil, 1977.

36. On this episode, see V.Sidane, Le Printemps de Pékin (Beijing Spring), Paris, Gallimard, 1981

37. A collection of the documents from the Democracy Wall has been published in Hong Kong by Claude Widor, Documents on the Chinese Democratic Movement: 1978-1980, Paris, Hong Kong, Editions de l'Ecole des Hautes Etudes en Sciences Sociales, the Observer Publishers, Vol. 1, 1981, and Vol. 2, 1984.

38. When Wuer Kaixi and other student leaders visited France, they discovered their predecessors' ideas in Widor's books.

39. See the case of Wang Juntao, the editor of the moderate underground journal Beijing zh chun in 1978-79, who took an active part in the movement in May 1989. 


\section{A Chinese "Memorial"?}

The blackout in history and in official memory of the 1989 movement also acts as an obstacle to the development of an opposition. Not a single book or newspaper article published on the mainland since 1989 has ever referred to the movement in a positive or even objective light. The authorities are very cautious, and every year they are particularly nervous during the two-months "sensitive period" (minggan shiqi) between 15 April and 4 June. ${ }^{(40)}$ Until 2003, during these two months, plainclothes and uniformed policemen were on high alert not to let anyone stage the slightest act looking like protest, and every June 4 - the anniversary of the massacre - the cemetery at Babaoshan has been placed under the military's quasi-occupation, with the CCP anxious to prevent any kind of gathering by relatives mourning the victims of the massacre. Although history, as officially presented in books and the press, never mentions the events of 1989, the term liu si (June 4), which recalls the officially recognized wu si (May 4" Movement) and si wu (the April 5 "Tiananmen Incident of 1976), is extensively used by ordinary citizens as well as historians and even Party cadres in private conversation, and, of course, while abroad.

This reference shows that things have changed since Mao's days, when even in personal memories political events were only referred to by their official names. When, instead of calling an event by its official name, ordinary people use the term preferred by the opposition, it can be taken as a breach in the state's monopoly on interpretation of history. During the years that immediately followed the Tiananmen massacre, while the official media never referred to it, most Beijingers kept talking about the event. In private debates among intellectuals, analysis of the 1989 events remained a key topic all through the 1990s. Discussions about how to speed up democratization always refer to this movement, whose importance is universally recognized. ${ }^{(41)}$ However, one may only speak of liu si in private or abroad. In the public sphere, the Party's monopoly view remains intact. In these circumstances, it is hard to gauge to what extent the 1989 experience forms part of the common heritage of Chinese citizens.

The difficulty of transmitting memory has impeded the prodemocracy movement from accumulating experience. Each episode of resistance appears isolated to actors who see themselves as radical innovators. The 1989 students were convinced that they had been the first in the PRC's history to have launched a real challenge to the CCP, and failed to see that they were only successors to a long line of resisters.
(The same could be said of the Red Guard generation). This inability to capitalize on the memory of previous episodes of resistance, which is obviously also due to the Party's ban on remembrance, has resulted in a segmentation that has had a negative impact on the structuring of a political opposition.

The history of resistance since 1949 has yet to be written (in China or abroad). But so long as there is no structured memory of past experience, it is difficult to imagine the emergence of a well organized opposition movement. Drawing lessons from the past to avoid repeating errors is an important task for any political organization, for just as the legitimacy of a political regime is always grounded in history, opposition movements also need historical references. Especially in a country such as China, where government historians (and quite a few foreign specialists) tend to describe the quest for democracy as alien to the ancient land's culture, a detailed history of movements resisting despotism would certainly provide sustenance to the forces that fight for democracy.

The example of the Memorial Movement in the final years of the Soviet Union ${ }^{(42)}$ illustrates this point. Mikhail Gorbachev let memory resurface as part of his policy of Glasnost in order to deny his opponents historical legitimacy and to show that Communism had been much more multifaceted than implied by the interpretation under Leonid Brezhnev. The resurgence of the victims' version of history and the revision of episodes of resistance were instrumental to the de-legitimization of his opponents.

China has yet to organize a Memorial Movement. Even the great writer Ba Jin's proposal to build a museum of the Cultural Revolution was rejected by the authorities. ${ }^{(43)}$ No reference to the 1989 Democracy movement can be found in official publications, and many victims of campaigns launched by Mao and his successors still await rehabilitation.

The request for dialogue that was at the centre of the movement that took place nearly 19 years ago has not been dis-

40. 15 April 1989 is the day Hu Yaobang died, triggering the student demonstrations. On June 4, troops marched on Tiananmen, killing hundreds of unarmed protesters.

41. Not long ago, in an open letter demanding political reforms, a People's Congress deputy from Anhui, Wang Zhaojun, called for re-evaluation of the June 4 events: http://www.epochtimes.com/gb/7/10/23/n1877443.htm and http://www.epochtimes.com/gb/7/10/23/n1877443.htm (last visited 4 February 2008).

42. This organisation, which demanded a memorial to the victims of Stalinism, was founded in 1987. It still exists, and besides its task of writing the obliterated history of Soviet repression, it also defends human rights.

43. Ba Jin, "Wenge bowuguan (A museum of the Cultural Revolution)," Suixiang Iu (Ba Jin's Random Thoughts), Beijing, Sanlian shudian, 1987, Vol.2, pp. 819-823. 
Propaganda poster from the time of the Anti-Hu Feng campagn, calling to "Resolutely eliminate the counter-revolutionary Hu Feng clique, and all hidden counter-revolutionaries." ( ) IISH Stefan R. Landsberger Collection, http://www.iisg.nl/ landsberge

(ת)

cussed publicly. Cyberspace has provided a locus for dialogue, and one can only hope that it will help dissenters and resisters draw lessons from past failures. In the private domain, memory can no longer be obliterated. Will it be able to overcome the monopoly on the writing of history still held by the CCP? Is the emergence of a Memorial Movement a prerequisite to the structuring of a Chinese opposition movement?

For about a decade, a number of intellectuals have been trying to write another history of the PRC through recourse to oral history and by collecting individual memories. They generally meet inside China or abroad and publish their works whenever there is an opportunity. The historian Ding Dong has founded a review entitled Lao Zhaopian (Old photographs) in which he publishes accounts by ordinary people or political leaders from both the Republican and PRC eras, presented through photographs culled from family albums. The editor's design is to present individuals' recollections of the past, which in some cases make way for a description of events that are not mentioned in official history. Despite the obstacles it often encounters, the project still continues. Meanwhile, liberal intellectuals such as $\mathrm{Xu}$ Youyu try to publish accounts of the Cultural Revolution, beginning with their own autobiographies. ${ }^{(4)}$ The People's Daily journalist Li Hui, who specialises in biographies of writers, has also written about the victims of several movements during the Mao era. He has published a book on the movement against the literary critic Hu Feng, which used documents from the 1950s to objectively retrace the campaign. ${ }^{(4)}$ Also worth mentioning is the book You jianle zuotian by Du Gao. ${ }^{(4)}$ Li Hui once happened to buy at the Panjiayuan flee market a dossier discarded by a danwei (work unit), which turned out to be personal file (dang'an) of Du $\mathrm{Gao}$, who had been accused of being a supporter of $\mathrm{Hu}$ Feng in the early 1950s. Du was cleared at the time, but was labelled a Rightist in 1957. Li gave Du photocopies of his file, extracts of which he has published in their historical context, thus making it an original type of autobiography. This book shows how the authorities dealt with suspects, and how monitoring of private conversations was used to indict the speakers. It is a meticulous description of the work of CCP cadres during a political movement. Some personal files of Rightists have also been published.

Thus, despite censorship and the obstacles raised by the propaganda department, interesting texts emerge even from official publishing houses. One can expect this trend to grow, and it might well lead to the creation of a Chinese Memorial more complex than its Soviet counterpart. The cur-

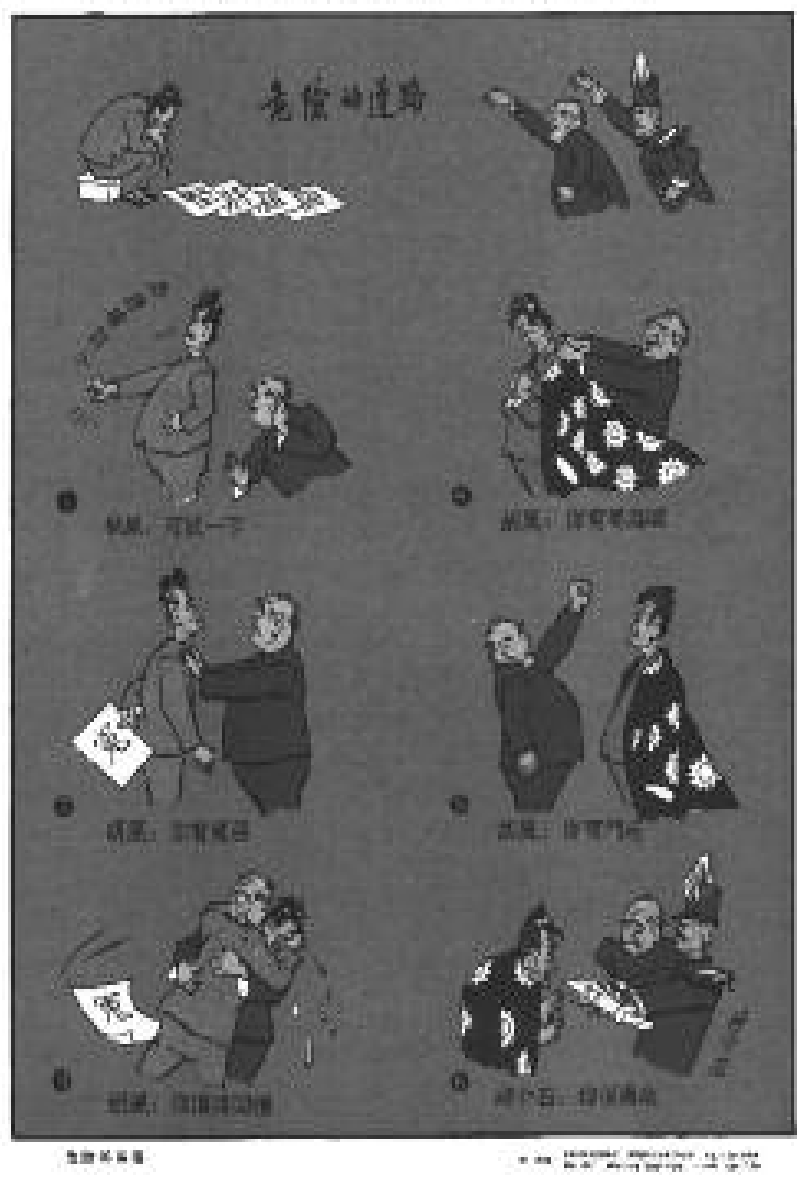

rent semi-official movement that slips through the cracks of political control does not appear as well structured as its Soviet predecessor. Its influence on collective conscience is likely to be weak, and it will have no direct effect on the eventual structuring of an opposition movement. On the other hand, it could emerge without having to wait for a reformer to take over the Party leadership. The famously opaque Chinese regime may yet have many tricks up its sleeve.

\section{- Translated with the collaboration of N. Jayaram}

\begin{tabular}{llll} 
Glossary & & \multicolumn{2}{c}{ Qiuhou suanzhang 秋後算帳 } \\
yi ku & 憶苦 & xiang qian kan & 向前看 \\
si tian & 思甜 & Minzhu Qiang & 民主牆 \\
yinmoujia & 陰謀家 & Tansuo & 探索 \\
jieji ganqing & 階级感情 & Siwu luntan & 四五論壇 \\
yiku fan & 憶苦飯 & mingan shiqi & 敏感時期 \\
huaqing jiexian & 劃清界限 & Lao Zhaopian & 老照片 \\
da chuanlian & 大串連 & You jianle zuotian & 又見了昨天 \\
Liandong & 聯動 & Wode zaofan & 我的造反 \\
Dang tianxia & 黨天下 & shengya & 生涯 \\
Guangchang & 廣場 & Wenge de qiyin & 文革的起因 \\
& & &
\end{tabular}

44. Xu Youyu, "Wode zaofan shengya (My experience of "rebellion")," in Xu Youyu, Ziyou de yanshuo (Paroles libres), op.cit., p. 24-51, and "Wo qinli guo de wudou (My experience of armed struggle)," pp. 24-52.

45. Li Hui, Hu Feng jituan yuan'an shimo, Wuhan, Hubei renmin chubanshe, 2003.

46. You jianle zuotian, Beijing, Shiyue wenyi chubanshe, 2004. 